\section{North Carolina adopts its own rules \\ Washington}

IN a move that could usher in a state-bystate approach to the regulation of biotechnology in the United States, the state of North Carolina voted last week to adopt its own rules governing the release of genetically engineered organisms into the environment. North Carolina's legislature passed a law requiring state permits for all field tests of genetically engineered organisms, in addition to the approval already required by US government agencies.

The law - drafted by an unlikely coalition of environmentalists, academics, state government officials and biotechnology industry representatives - seeks to protect the public and prevent local opposition to field tests. All the field tests of genetically engineered organisms carried out so far in the United States have met with some resistance at county or municipal level - with the 1986 California test of the 'ice-minus' bacteria that would shield plants from frost as the most notorious example. By setting up an in-state review system, North Carolina aims to reassure its citizens while encouraging biotechnological innovations that could benefit its large agricultural industry.

The North Carolina law creates a 10-member Genetic Engineering Review Board that includes the state's commissioner of agriculture, a working farmer, someone from a 'public interest' organization and a representative from the biotechnology industry. The board will write detailed regulations that the state's agriculture department will use when it begins to evaluate field test requests next year. The rules will apply to both academic and industrial researchers. Those who conduct tests without approval will be fined; there is no limit on the amount of damages an infringer would pay if an experiment were to go awry.

The US Environmental Protection Agency (EPA) has been struggling for more than two years to amend the Toxic Substances Control Act to cover biotechnology (see Nature 337, 681; 1989). One proposal, vigorously opposed by biotechnology companies, would have created local boards to review proposed experiments. EPA officials have expressed puzzlement over why the biotechnology industry should now embrace similar regulations.

Other states may follow North Carolina's example. Illinois and Wisconsin already require notification of field tests of genetically engineered organisms, and in June this year Minnesota set up an Environmental Quality Board with the aim of coordinating state and federal regulations pertaining to such tests. The states of New York, New Jersey and Washington are also considering similar laws.

Carol Ezzell

\title{
Meitner receives her due
}

\section{Munich}

FIFTY years after she participated in the discovery of nuclear fission and 21 years after her death, Lise Meitner is finally to be given full recognition for her achievements in West Germany. After years of lionizing her co-worker Otto Hahn, the Deutsches Museum in Munich agreed last week to give Lise Meitner equal credit in its portrayal of the discovery. Hahn, Meitner and Fritz Strassmann collaborated in the discovery of the fission of uranium in Berlin in 1938-39, for which Hahn won the 1944 Nobel prize. Hahn and Meitner both died in 1968 at the age of 89.

On the first floor of the Deutsches Museum, a laboratory table containing an apparatus for the neutron irradiation of uranium, which was thought to be used in the discovery, is labelled "worktable of Otto Hahn". But the apparatus was

\section{IMAGE UNAVAILABLE FOR COPYRIGHT REASONS}

Deutches Museum, Munich, has promised that the label on "Hahn's" laboratory table will be altered to give equal recognition to Meitner. designed by Meitner in the physics section of the Kaiser Wilhelm Institute for Chemistry before she had to flee to Sweden in 1938. Meitner, an Austrian Jew, feared dismissal by the Nazis. A caption describes Meitner as a "Mitarbeiterin", which literally means "co-worker" but in German carries the implied meaning of "subordinate". Meitner was not mentioned at all until the caption was rewritten in February 1989 on the orders of museum director Otto Mayr. Mayr says the museum will change the label to give equal recognition to Meitner.

Much of the credit for the reassessment of Meitner must go to Ruth Sime, a historian from Sacramento, California. Sime, who is writing the first scholarly biography of Meitner, presented a paper on Meitner last week at a congress for historians of science that took place, ironically, in the Deutsches Museum itself.

The presentation by Sime received "the closest thing to a standing ovation I have ever seen at a congress", said one participant. And it proved to be the last straw in a long series of complaints about the caption. Immediately afterwards, West German historian Barbara Orland of West Berlin circulated a petition asking for a change to the caption.

Sime explains that Meitner, in a letter dated 21 December 1938, encouraged Hahn to believe the unbelievable result that the uranium nucleus was not growing when it was bombarded by slow neutrons, as they had thought earlier, but was splitting into smaller nuclei like barium, with the potential release of tremendous amounts of energy. Hahn, a chemist, would later deny that the science of physics had contributed to the discovery. But on 27 December 1938, he added a paragraph on fission to the page proofs of a paper in the journal Die Naturwissenschaften. Meitner and her nephew Otto R. Frisch published a theoretical paper on the phenomenon in Nature a few months 旁 later $(143,239 ; 1939)$.

\& Hahn, one of a handful of non-Nazis in his ¿institute, was fearful of losing his chair to a rival. He denied having consulted with Meitner in order to protect himself from attacks by physicists who had remained in the institute after Meitner had left. According to Sime, Meitner was badly hurt when Hahn continued to deny her role after the war.

Hahn became one of the few scientific heroes in a demoralized postwar Germany. After returning from internment in Britain in 1946, Hahn (who became the first president of the Max Planck Society) worked hard to ensure that German science rose from the ashes. As West German historian Fritz Krafft has pointed out, Hahn's version of the discovery came to dominate all others, and something of a personality cult grew up around Hahn among his pupils and collaborators.

Mayr, who disputes the existence of a Hahn personality cult, says he nominated Meitner for the museum's "Hall of Fame" in February, before the latest row. The hall contains busts of 38 "German" scientific greats, from Copernicus (a Pole) to Einstein. He expects her to be installed next May. Meitner, who found it to be "half a crime to be a woman" in a Swedish scientific laboratory, says Sime, will thus gain admittance, albeit posthumously, to at least one exclusive club. All other members of the hall are male.

Steven Dickman 